\title{
SUMEGe
}

International Journal of Environment and Geoinformatics (IJEGEO) is an international, multidisciplinary, peer reviewed, open access journal.

\section{Multi-Criteria Selection of Suitable Institutional Solid Waste Collection Sites: A Case of KNUST Campus, Kumasi, Ghana}

\author{
Alhassan SULEMANA, Eric K. FORKUO, Evelyn T. ARTHUR, Kwame \\ AGYEI-GYAMFI, Ebenezer OTCHERE-DARKO, Michael K. AYAIM
}

\author{
Chief in Editor \\ Prof. Dr. Cem Gazioğlu \\ Co-Editors \\ Prof. Dr. Dursun Zafer Şeker, Prof. Dr. Şinasi Kaya, \\ Prof. Dr. Ayşegül Tanık and Assist. Prof. Dr. Volkan Demir
}

Editorial Committee (December 2020)

Assos. Prof. Dr. Abdullah Aksu (TR), Assit. Prof. Dr. Uğur Algancı (TR), Prof. Dr. Bedri Alpar (TR), Prof. Dr. Levent Bat (TR), Prof. Dr. Paul Bates (UK), İrşad Bayırhan (TR), Prof. Dr. Bülent Bayram (TR), Prof. Dr. Luis M. Botana (ES), Prof. Dr. Nuray Çağlar (TR), Prof. Dr. Sukanta Dash (IN), Dr. Soofia T. Elias (UK), Prof. Dr. A. Evren Erginal (TR), Assoc. Prof. Dr. Cüneyt Erenoğlu (TR), Dr. Dieter Fritsch (DE), Prof. Dr. Çiğdem Göksel (TR), Prof.Dr. Lena Halounova (CZ), Prof. Dr. Manik Kalubarme (IN), Dr. Hakan Kaya (TR), Assist. Prof. Dr. Serkan Kükrer (TR), Assoc. Prof. Dr. Maged Marghany (MY), Prof. Dr. Michael Meadows (ZA), Prof. Dr. Nebiye Musaoğlu (TR), Prof. Dr. Masafumi Nakagawa (JP), Prof. Dr. Hasan Özdemir (TR), Prof. Dr. Chryssy Potsiou (GR), Prof. Dr. Erol Sarı (TR), Prof. Dr. Maria Paradiso (IT), Prof. Dr. Petros Patias (GR), Prof. Dr. Elif Sertel (TR), Prof. Dr. Nüket Sivri (TR), Prof. Dr. Füsun Balık Şanlı (TR), Prof. Dr. Uğur Şanlı (TR), Duygu Ülker (TR), Prof. Dr. Seyfettin Taş (TR), Assoc. Prof. Dr. Ömer Suat Taşkın (US), Assist. Prof. Dr. Tuba Ünsal (US), Dr. İnese Varna (LV), Dr. Petra Visser (NL), Prof. Dr. Selma Ünlü (TR), Prof. Dr. Murat Yakar (TR), Assit. Prof. Dr. Sibel Zeki (TR)

Abstracting and Indexing: TR DIZIN, DOAJ, Index Copernicus, OAJI, Scientific Indexing Services, International Scientific Indexing, Journal Factor, Google Scholar, Ulrich's Periodicals Directory, WorldCat, DRJI, ResearchBib, SOBIAD 


\title{
Multi-Criteria Selection of Suitable Institutional Solid Waste Collection Sites: A Case of KNUST Campus, Kumasi, Ghana
}

\author{
Alhassan Sulemana ${ }^{1, *}$, (iD Eric K. Forkuo ${ }^{2}$, (D) Evelyn T. Arthur ${ }^{1}$, (D) Kwame Agyei-Gyamfi ${ }^{1}$, Ebenezer \\ Otchere-Darko ${ }^{1}$, (iD) Michael K. Ayaim ${ }^{1}$ (D)
}

${ }^{1}$ Department of Environmental Science, Kwame Nkrumah University of Science and Technology, Kumasi, Ghana

${ }^{2}$ Department of Geomatic Engineering, Kwame Nkrumah University of Science and Technology, Kumasi, Ghana

* Corresponding author: A. Sulemana

* E-mail: sulemanaalhassan@knust.edu.gh

Received 28 Feb 2020 Accepted 13 Oct 2020

How to cite: Sulemana et al. (2020). Multi-Criteria Selection of Suitable Institutional Solid Waste Collection Sites: A Case of KNUST

Campus, Kumasi, Ghana, International Journal of Environment and Geoinformatics (IJEGEO), 7(3): 372-380. DOI: 10.30897/ijegeo.696335

\begin{abstract}
Solid waste receptacles siting is becoming increasingly difficult due to increase in population and infrastructure development that has limited available space for waste collection. This study focused on selection of environmentally friendly sites for waste receptacle placement in Kwame Nkrumah University of Science and Technology (KNUST) based on multi-criteria decision analysis in a geographic information system (GIS) environment. ArcGIS software was used in overlaying different thematic maps in order to generate suitable areas for siting communal containers and small bins. Environmental criteria considered include river bodies, vegetation, road network, buildings, car park and slope. The analytical hierarchy procedure was used to determine the weight of each criterion used in finding the suitable sites. The final suitability maps generated showed areas deemed suitable for siting communal containers and small bins. Out of the total land area of KNUST $\left(10.35 \mathrm{~km}^{2}\right), 0.86 \mathrm{~km}^{2}$ representing $8.31 \%$ was suitable for siting small bins. For communal containers, the final suitability map indicated that $1.69 \mathrm{~km}^{2}(16.33 \%)$ and $0.73 \mathrm{~km}^{2}(7.05 \%)$ of the total land area were suitable and most suitable sites respectively. The findings from this study serve as guidance tool for environmentally friendly solid waste receptacle siting and good health promotion with efficient land use planning.
\end{abstract}

Keywords: Solid Waste Collection, Receptacles Siting, GIS, MCDA, AHP

\section{Introduction}

Solid waste management constitutes one of the major environmental sanitation problems, particularly to urban areas in developing countries. The continuous economic development, growing human population, changes in habits and lifestyle, rising disposal income coupled with increasing demand for goods and services have resulted in increasing waste quantities and variety (Guerrero et al., 2013). Even though cities in developing countries are using $20 \%-50 \%$ of their budget in solid waste management, only $20 \%-80 \%$ of the waste is collected (Awunyo-Vitor et al., 2013). The uncollected or illegally dumped wastes create a disaster for human health and cause environmental degradation. The waste management challenges put urban councils in a difficult situation as they have to implement new methods to deal with the increasing rate of wastes production. Waste receptacle siting is also becoming increasingly difficult due to growing environmental awareness, decreased government and municipal funding and extreme political and social opposition. The increasing population densities, public health concerns and less land available for landfill construction are also the difficulties to overcome (Şener et al., 2006).

The main problem in selecting suitable sites for container placement, especially in institutional premises for solid waste collection is the lack of baseline information about the topographic conditions, incompatible environmental components, existing landuse patterns and socio-economic concerns. Municipal or household wastes are often generated from several sources where variable human activities are encountered, institutions inclusive (Miezah et al., 2015). Kwame Nkrumah University of Science and Technology (KNUST) campus serves as an area of various human activities aimed towards successful academic and research welfare. The population of students in the school has escalated over the years resulting in the production of higher quantities of solid waste. The corresponding land area required for waste receptacles placement has gradually increased. Placing of waste receptacles that will be environmentally friendly is an extremely difficult task to accomplish because the site selection process depends on different factors and regulations as indicated by Ayaim et al. (2019). Environmental factors considered in siting waste management facilities include water bodies, vegetation, faultline, residential facilities, roads, slope, etc. Economic factors include the costs associated with acquisition and operation of the waste management site whiles social factors involve the acceptance by the intended target group of people.

This study highlighted the use of a GIS-based multicriteria selection in generating suitable sites for waste receptacle placement on KNUST campus. Geographic information system (GIS) and the analytical hierarchy process (AHP) were used as decision support systems to 
aid in the site selection. The GIS tool is used to manipulate and present spatial data, while the AHP is used to rank potential areas based on a wide variety of criteria, including hydro-geology, land use and proximity from urban centers (Al-Jarrah and Abu-Qdais, 2006; Khorrami et al., 2018). Several researches have been conducted with the use of this same approach for site selection especially for landfills, transfer stations and other waste management facilities but none of such has been conducted in an institutional setting for receptacles placement (Şener et al., 2010; Feizizadeh and Blaschke, 2013; Gorsevski et al., 2012; Direk et al., 2012; Bosompem et al., 2016; Vaghela et al., 2018; Büyüksalih et al., 2019; Mohammadı and Hosseınalı, 2019; Jimoh et al., 2019).

Just like siting landfills, this study required processing variety of spatial and non-spatial data since it was conducted within an academic institution with faculty, residential and commercial facilities to provide two suitability maps that serve as guidance tool for the University infrastructural managers on how to properly place communal containers and small bins to ensure environmental conservation. Covering an area of about $10.35 \mathrm{~km}^{2}$, KNUST is located in the eastern part of Kumasi in the Ashanti Region of Ghana, lying between latitude $6.6811^{\circ} \mathrm{N}$ and longitude $-1.5635^{\circ} \mathrm{W}$ (Figure 1). The elevation of KNUST ranges from $250-300 \mathrm{~m}$ above sea level. It is bounded by some neighboring suburbs including Ayigya, Bomso, Ayeduase, Kotei and Gyenyaase. It is located in the transitional forest zone; and lies about $270 \mathrm{~km}$ north of the national capital, Accra. Solid waste collection within KNUST can be categorized into two based on the size of receptacles: communal containers $\left(12 \mathrm{~m}^{3}\right.$ capacity) and pegged/small bins (120/240 L capacities). The pegged and small bins collections are done using compactor trucks while the communal bins are collected using skip trucks. The university had four compactor trucks and three skip trucks at the time of data collection.

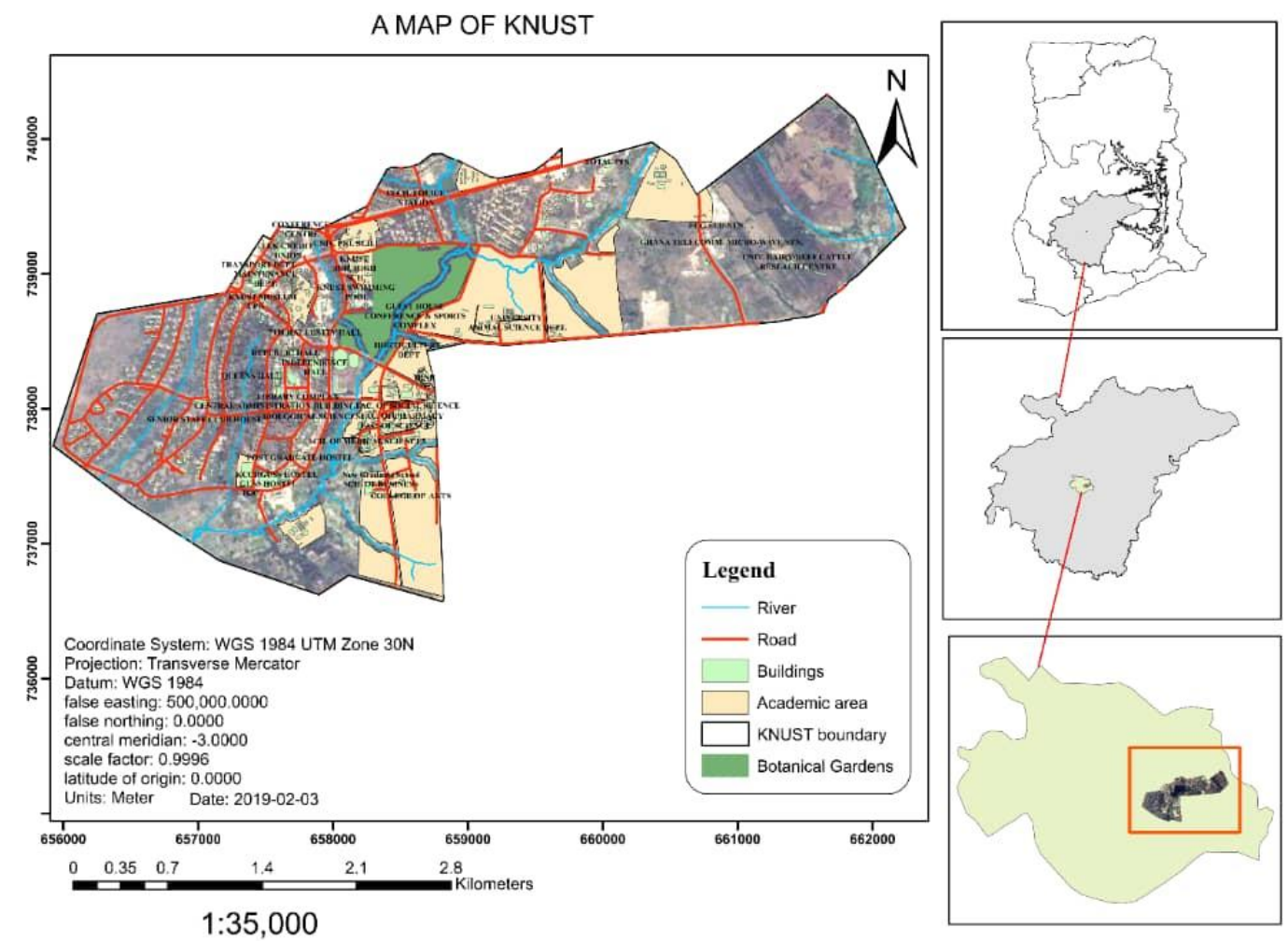

Figure 1. Map of KNUST showing environmental features (Sulemana et al., 2020)

\section{Materials and Method Materials and Software}

For the purpose of this study, both soft and hard copied data on locations of the existing receptacles sites, types and numbers as well as the collection systems obtained from the Environmental Quality Unit of KNUST were used. Shapefiles which included KNUST boundary, academic area, buildings, car parks, vegetation, and rivers together with relevant topographical maps were obtained from the Geomatic Engineering Department of the University and an online database (Open Street Map). A satellite image of the study area showing the current waste collection sites was obtained with the help of Google Earth software.
The study employed Spatial Analyst extension within ArcGIS 10.3 Software for all data processing: creating, visualizing, querying and analyzing geospatial data. This software provided common features and functions and supported a number of raster data format. All the supported raster and vector data types used were converted into compatible formats that the software could interpret. Multi-criteria Decision Analysis (MCDA) was integrated into the software since they complement each other. GIS served as a very useful tool to store, analyze and manipulate all the spatial data used for decision making and the MCDA provided a set of procedures and algorithms for the structuring, designing 
and evaluating of decision problems as reported by Feizizadeh and Blaschke (2013). For data analysis and performing pairwise comparison computations, Microsoft Excel 2013 application was used.

\section{Methods}

\section{Analytical hierarchy process}

The study employed the use of the AHP for the decision analysis of data for siting solid waste collection receptacles. This method is designed to enhance sound decision making by using both empirical data as well as subjective judgments of the decision maker. Each set of elements in a pairwise fashion with respect to each of the elements in a higher stratum was evaluated. The evaluation was done by off-diagonal relationship in one half of each matrix. It used a 9-point scale which ranged from 1; equal importance to 9; extreme preference (Table 1).

Table 1. Relative importance in pairwise comparison criteria (Şener et al., 2010)

\begin{tabular}{ll}
\hline Criteria & Degree of Importance \\
\hline 1 & Equally important \\
2 & Equal to moderately important \\
3 & Moderately important \\
4 & Moderately to strongly important \\
5 & Strongly important \\
6 & Strongly to very strongly important \\
7 & Very strongly important \\
9 & Very to extremely strongly important \\
\hline
\end{tabular}

The calculation of the weights involved several steps: (1) all the judgments on the column basis were summed up, (2) the normalized matrix was calculated, and (3) values gotten from the sum across the row represented every criterion which led to the calculation of the priority values. The averages obtained gave an estimated value of the relative weights of the various criteria selected. Consistency Index (CI) was calculated to determine the consistency ratio (Equation 1). Consistency Ratio (CR) was estimated to ascertain if the judgments were biased or not. It was computed by the weighted sum values divided by the priority values (Equation 2). According to Saaty (1980), when CR $<0.10$, a level of consistency is said to be achieved and if $C R \geq 0.10$, then the judgments are inconsistent (Table 2). Where $\mathrm{CI}=0$, then a perfectly consistent pairwise comparison exists.

$$
C I=\frac{\lambda \max -n}{n-1} \quad E q 1
$$

Where $n=$ number of criteria and $\lambda=$ average value of the consistency vector.

$$
C R=\frac{C I}{R I} \quad E q 2
$$

\section{Digitizing, buffering and thematic map preparation}

All geographic data obtained were digitized (converted from analogue to vector or digitized format) to make images very compatible with geo-processing formats. Relevant environmental features of the study are were digitized and new feature class was created for each feature under the Universal Transverse Mercator (UTM) zone $17 \mathrm{~N}$. Buffering as a geo-processing technique was used to determine unacceptable areas for siting waste receptacles. Unacceptable areas determined after buffering were areas with greater height and slope, faults, surface water sources, ground water sources, residential areas, road network and even commercial areas. Buffers were created around these areas in the form of lines and polygons measured in units of distance to produce various thematic maps for each environmental criterion considered. Standardizations used for buffering in order to site communal and smaller bins are presented in Tables 3 and 4.

Overlay analysis

After creation of all thematic maps based on the selected criteria, an overlay analysis was done to put them together to identify the relationships between all the maps. Overlay analysis was conducted in GIS

Table 2. Random index table (Saaty, 1980)

\begin{tabular}{lllllllllll}
\hline $\mathrm{n}$ & 1 & 2 & 3 & 4 & 5 & 6 & 7 & 8 & 9 & 10 \\
\hline $\mathrm{RI}$ & 0.00 & 0.00 & 0.58 & 0.90 & 1.12 & 1.24 & 1.32 & 1.41 & 1.45 & 1.49 \\
\hline
\end{tabular}

Table 3. Standardization of data for communal bins

\begin{tabular}{llll}
\hline Criteria & Unsuitable (1) & Suitable (2) & Most Suitable (3) \\
\hline Residential Areas & $<100 \mathrm{~m}$ & $>250 \mathrm{~m}$ & $100 \mathrm{~m}-250 \mathrm{~m}$ \\
River & $<90 \mathrm{~m}$ & $200 \mathrm{~m}-940 \mathrm{~m}$ & $90 \mathrm{~m}-200 \mathrm{~m}$ \\
Road & $<50 \mathrm{~m}$ & $>150 \mathrm{~m}$ & $50 \mathrm{~m}-150 \mathrm{~m}$ \\
Slope & $<2 \%,>15 \%$ & $10 \%-15 \%$ & $2 \%-10 \%$ \\
\hline
\end{tabular}

Table 4. Standardization of data for smaller bins

\begin{tabular}{llll}
\hline Criteria & Unsuitable (1) & Suitable (2) & Most Suitable (3) \\
\hline Buildings & $>30 \mathrm{~m}-100 \mathrm{~m}$ & $15 \mathrm{~m}-30 \mathrm{~m}$ & $<15 \mathrm{~m}$ \\
River & $<50 \mathrm{~m}$ & $>100 \mathrm{~m}$ & $50 \mathrm{~m}-100 \mathrm{~m}$ \\
Road & $<10 \mathrm{~m}$ & $>20 \mathrm{~m}$ & $10 \mathrm{~m}-20 \mathrm{~m}$ \\
Botanical Gardens & $<250 \mathrm{~m},>800 \mathrm{~m}$ & $>400 \mathrm{~m}-800 \mathrm{~m}$ & $>500 \mathrm{~m}$ \\
Car Park & $<30 \mathrm{~m}$ & $>50 \mathrm{~m}$ & $30 \mathrm{~m}-50 \mathrm{~m}$ \\
\hline
\end{tabular}


environment to assign classes and theme weights for input parameters which were used to assign the importance of each input theme in calculating the overall suitability cumulative curve as reported by Walke et al. (2012). The final map was created to achieve an integrated analysis and hence most preferred locations to satisfy our objectives were identified.

\section{Development of criteria and criteria score standardization}

For evaluation of the criteria, a database was created and each criterion standardized in terms of suitability for siting waste collection receptacles on KNUST campus. The map layers (criteria) were standardized to a common scale using weighted overlay functions in the GIS context, making the criteria responsive to each other as indicated by Eastman et al. (1995). This method is mostly applicable in land use/suitability analysis, site selection and resource evaluation problems. The criteria used in this evaluation involved a numerical evaluation scale ranging from $1-3$, showing the scale of suitability; unsuitable, suitable and most suitable respectively. To achieve our aim of developing a suitable index map, the dataset which included all data in relation to the different criteria, was set to a common scale making it easier to combine the map layers using the weights computed from the pairwise comparison. This according to Drobne and Lisec (2009), highlights added advantages of the use of pairwise comparison method which provides an organized structure for group discussions, and helping the decision-making group focus on areas of agreement and disagreement when setting criterion weights.

\section{Results}

Results for the placement of waste receptacles on the entire area of KNUST were divided into two groups; placement of communal containers at the residential areas and that of small bins placement at the academic (faculty) and commercial areas as well as along major streets. This was done to apply different buffer distances to each category because of the nature of the two receptacles and the type of waste generated daily at the two areas. Communal containers are uncovered and kept to collect waste temporarily before it is transported to the final disposal site. This is unlike small receptacles that are covered and lined with trash bags to prevent scattering and odour. The further the buffer distance designated to place communal containers considering each criterion, the most suitable it became unlike small containers which were considered suitable when cited even close to the criterion of interest.

\section{Thematic Maps Developed for Communal Container Siting \\ Road network}

In relation to road as a criterion for siting communal container, an area of $3.80 \mathrm{~km}^{2}(36.67 \%)$ was considered as unsuitable region. Out of the total land cover of
KNUST $\left(10.35 \mathrm{~km}^{2}\right), 3.23 \mathrm{~km}^{2}(31.21 \%)$ portion of the land was considered suitable and the remaining area $\left(3.32 \mathrm{~km}^{2}\right.$ ), representing $32.11 \%$ was depicted as most suitable for placing communal container. The output of the proximity analysis is presented in Figure 2.

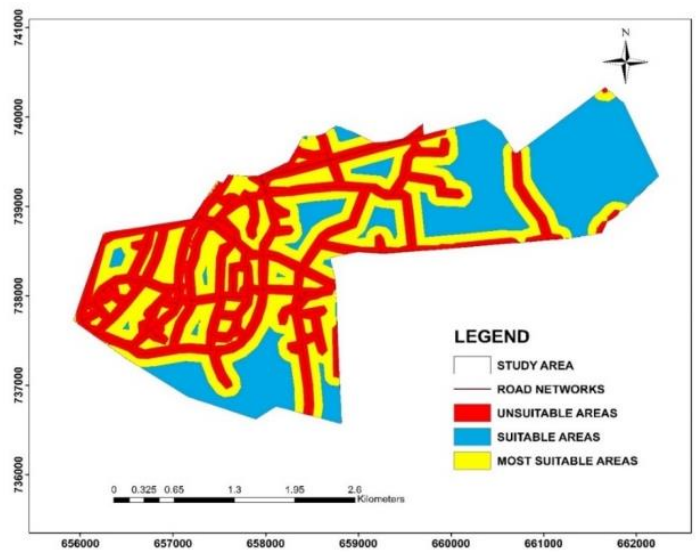

Figure 2. Suitability map for road network

\section{Built area}

Classification of the study area based on built area criterion for siting communal containers is presented in Figure 3. Most suitable area covered $2.63 \mathrm{~km}^{2}(25.43 \%)$ whereas $2.03 \mathrm{~km}^{2}(19.63 \%)$ and $5.69 \mathrm{~km}^{2}(54.94 \%)$ represented suitable and unsuitable areas respectively.

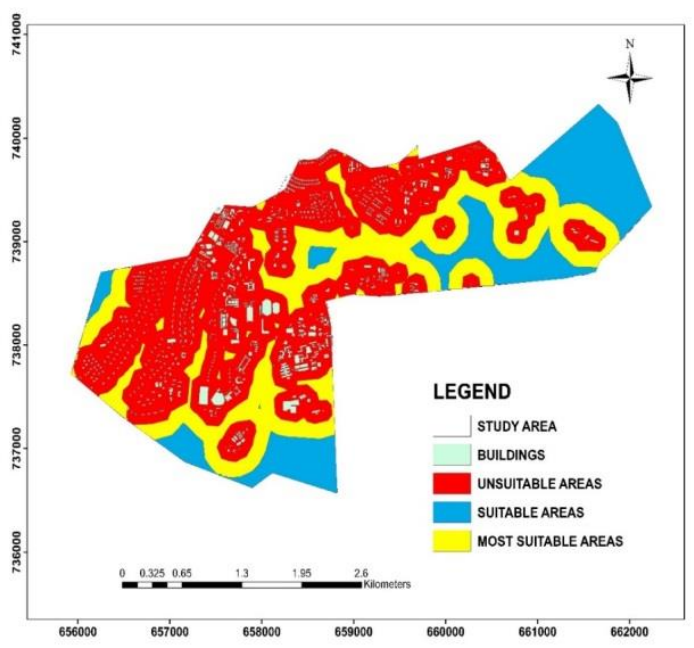

Figure 3. Suitability map for built areas

\section{River body}

Proximity analysis based on river body indicated an area of $2.97 \mathrm{~km}^{2}(28.71 \%)$ as most suitable whiles $4.32 \mathrm{~km}^{2}$ $(41.69 \%)$ and $3.06 \mathrm{~km}^{2}(29.57 \%)$ were respectively considered as suitable and unsuitable areas for placing communal containers on KNUST campus as presented in Figure 4.

\section{Slope of land}

The outputs of proximity analysis for slope criterion for the three suitability indices are presented in Figure 5. Most suitable areas for siting communal containers in terms of this criterion was $0.77 \mathrm{~km}^{2}(7.44 \%)$. Suitable 
and unsuitable areas covered $1.16 \mathrm{~km}^{2}(11.22 \%)$ and $8.42 \mathrm{~km}^{2}(81.34 \%)$ respectively.

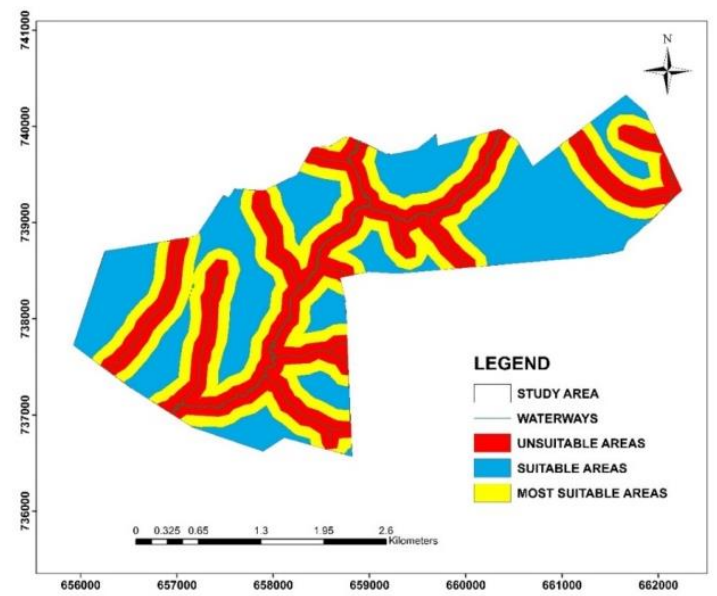

Figure 4. Suitability map for river body

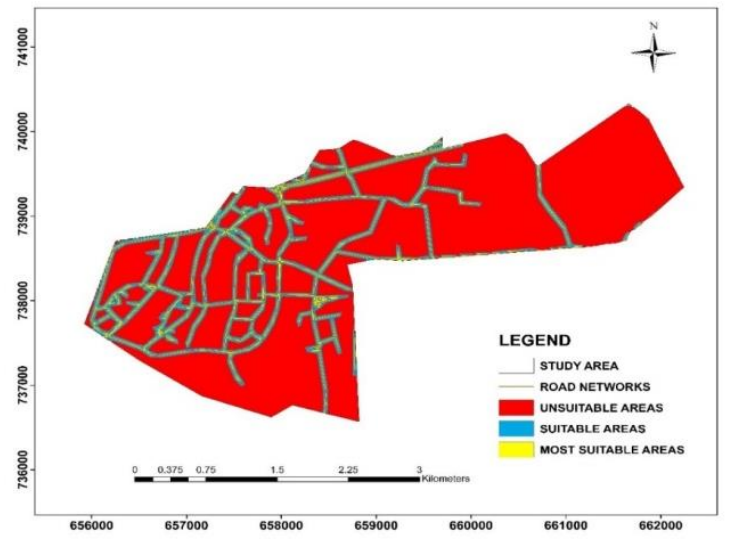

Figure 6. Suitability map for road network

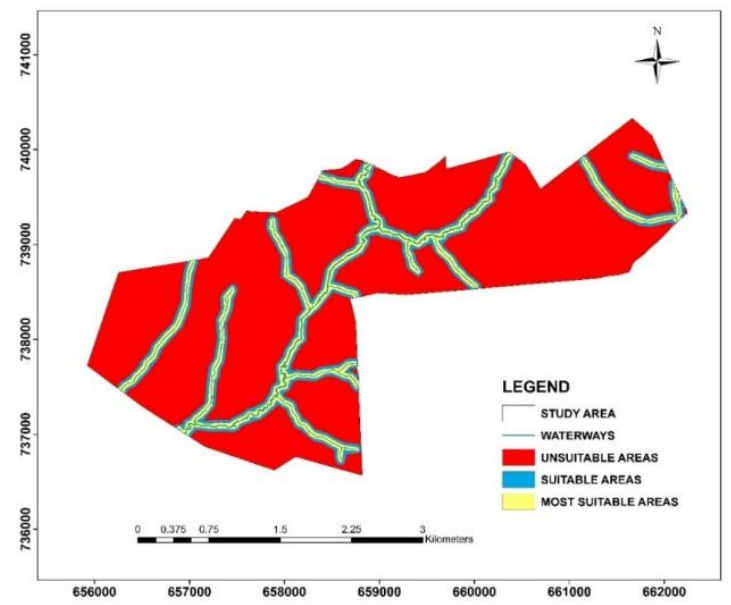

Figure 8. Suitability map for river

\section{Thematic Maps Developed for Small Bin Siting}

\section{Road network}

Classification of the study area based on road criterion for siting small bins is presented in Figure 6. An area of $0.77 \mathrm{~km}^{2}(7.43 \%)$ was considered most suitable whereas $1.32 \mathrm{~km}^{2}(12.72 \%)$ and $8.262 \mathrm{~km}^{2}(79.83 \%)$ were considered as suitable and unsuitable areas respectively.

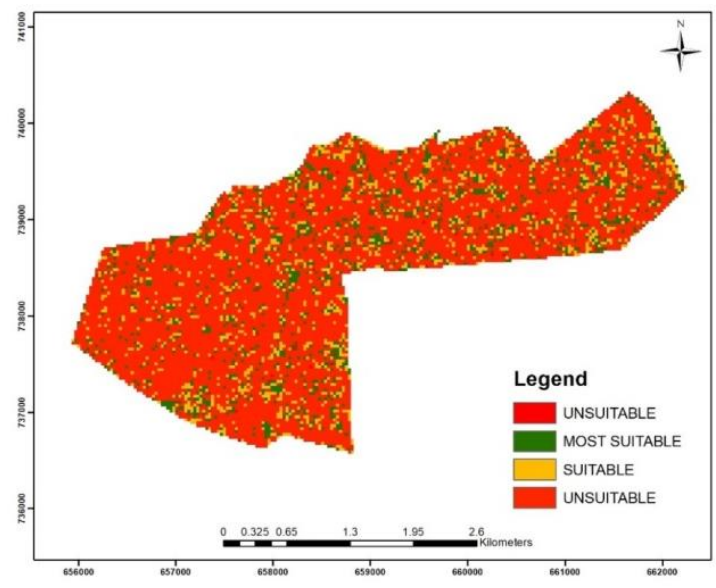

Figure 5. Suitability map for slope

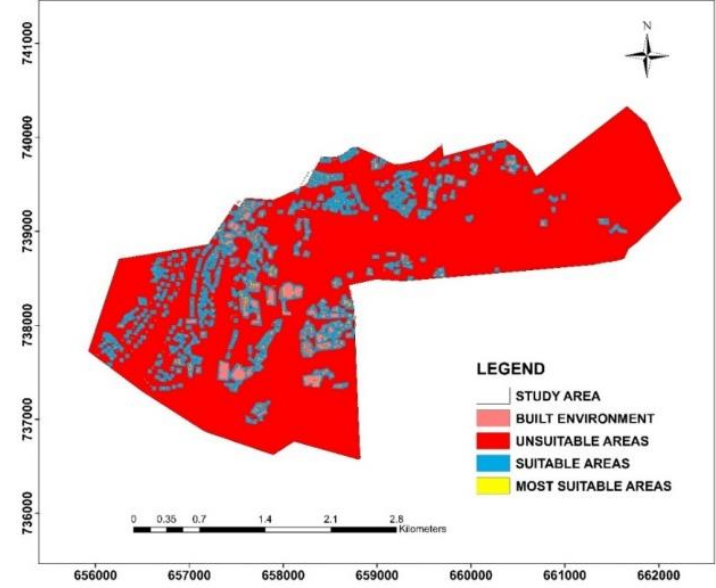

Figure 7. Suitability map for buildings

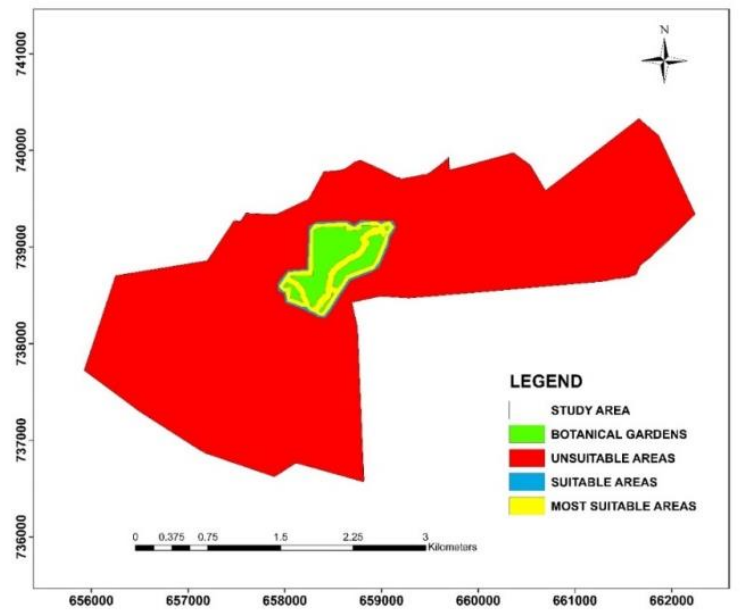

Figure 9. Suitability map for botanical garden

\section{Built area}

For built area, as Figure 7 depicts, an area of $0.43 \mathrm{~km}^{2}$, representing $4.19 \%$ of the total land area, was found to be most suitable for placement of small bins. $1.51 \mathrm{~km}^{2}$ of the area, representing $14.60 \%$ was deemed to be suitable. The remaining area $(81.21 \%)$ representing $8.41 \mathrm{~km}^{2}$, was considered unsuitable for small bins placement. 


\section{River body}

The output of proximity analysis for river body as a placement criterion for small bins is presented in Figure 8. An area of $1.02 \mathrm{~km}^{2}$, representing $9.68 \%$ was found to be most suitable for placement of small bins around the river body. $0.87 \mathrm{~km}^{2}$ of the total land area $(8.42 \%)$ was determined to be suitable for small bins placement. The remaining $8.46 \mathrm{~km}^{2}$ of the area, representing $81.69 \%$ was considered to be unsuitable for siting of small bins.

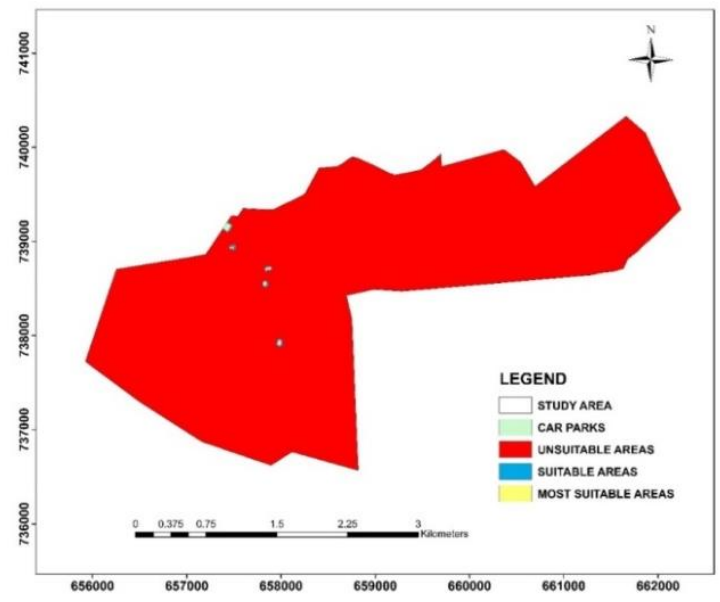

Figure 10. Suitability map for car park

\section{Vegetation cover}

Figure 9 depicts the suitability results obtained from the proximity analysis using vegetation as a placement criterion. From the results, it can be seen that, of the total land area, $0.62 \mathrm{~km}^{2}(6.05 \%)$ was considered most suitable. Suitable area for placing small bins covered an area of $0.07 \mathrm{~km}^{2}$, representing $0.65 \%$ and finally, areas considered as unsuitable made up $9.66 \mathrm{~km}^{2}$ of the total land size $(93.24 \%)$.

\section{Car park}

Considering car park as a criterion for small bin placement, Figure 10 depicts the outputs of the suitability analysis. An area of $0.01 \mathrm{~km}^{2}$, representing $0.91 \%$ was found to be most suitable for placement of small bins around car parks. Suitable area was $0.01 \mathrm{~km}^{2}$ $(0.11 \%)$. The remaining $10.33 \mathrm{~km}^{2}$ of the area, representing $99.82 \%$ was deemed to be unsuitable for siting of small bins.

\section{Weights of Suitability Criteria}

The AHP and Pairwise Comparison Matrices ensured that weights, that represent the level of importance of each criterion under study, were assigned respectively. Tables 5 and 6 show the pairwise comparison produced and the respective weights assigned using AHP for siting of communal containers and small bins respectively. For communal containers, a consistency ratio of 0.058 (< 0.1 ) was derived, depicting a level of consistency in the weight. Also, for small containers, a consistency ratio of 0.067 also indicating a level of consistency was derived.

\section{Suitable Sites for Solid Waste Collection}

The suitability result obtained for siting the communal containers after overlaying the respective thematic maps is presented in Figure 11. The overlay analysis provided results depicting unsuitable, suitable and most suitable areas. Out of the total land area $\left(10.35 \mathrm{~km}^{2}\right), 7.93 \mathrm{~km}^{2}$ representing $76.62 \%$ was classified as unsuitable, whereas $1.69 \mathrm{~km}^{2}(16.33 \%)$ was classified as suitable. Most suitable area for siting communal containers covered $0.73 \mathrm{~km}^{2}(7.05 \%)$. The overlay analysis for small bins depicted two classes; unsuitable area covering $9.49 \mathrm{~km}^{2}(91.69 \%)$ and suitable area covering $0.86 \mathrm{~km}^{2}$ $(8.31 \%)$ as presented in Figure 12.

Table 5. Computed weights from pairwise comparison for communal containers

\begin{tabular}{lccccc} 
Criterion & \multicolumn{3}{c}{ Categories } & Weights \\
\cline { 2 - 5 } & $\mathrm{Rd}$ & $\mathrm{B}$ & $\mathrm{R}$ & $\mathrm{S}$ & 0.0470 \\
\hline River & 0.20 & 0.11 & 1.00 & 0.25 & 0.1459 \\
Slope & 0.50 & 0.25 & 4.00 & 1.00 & 0.6031 \\
Built Areas & 5.00 & 1.00 & 9.00 & 4.00 & 0.2041 \\
Road & 1.00 & 0.20 & 5.00 & 2.00 & 1.0000 \\
Total & 6.70 & 1.56 & 19.00 & 7.25 & \\
\hline
\end{tabular}

$R d=$ Road, $B=$ Built areas, $R=$ River and $S=$ Slope

Table 6. Computed weights from pairwise comparison for small bins

\begin{tabular}{lcccccc}
\hline Criterion & \multicolumn{3}{c}{ Categories } & \multicolumn{2}{c}{ Weights } \\
\cline { 2 - 5 } & $\mathrm{Rd}$ & $\mathrm{B}$ & $\mathrm{R}$ & $\mathrm{V}$ & $\mathrm{C}$ & 0.3174 \\
\hline Road & 1.00 & 0.50 & 5.00 & 9.00 & 3.00 & 0.3844 \\
Built Areas & 2.00 & 1.00 & 5.00 & 9.00 & 2.00 & 0.0826 \\
River & 0.20 & 0.20 & 1.00 & 5.00 & 0.25 & 0.0302 \\
Vegetation Cover & 0.11 & 0.11 & 0.20 & 1.00 & 0.17 & 0.1854 \\
Car Park & 0.33 & 0.50 & 4.00 & 6.00 & 1.00 & 1.0000 \\
Total & 3.64 & 2.31 & 15.20 & 30.00 & 6.42 & \\
\hline
\end{tabular}

$R d=$ Road, $B=$ Built areas, $R=$ River, $V=$ Vegetation cover and $C=$ Car park 


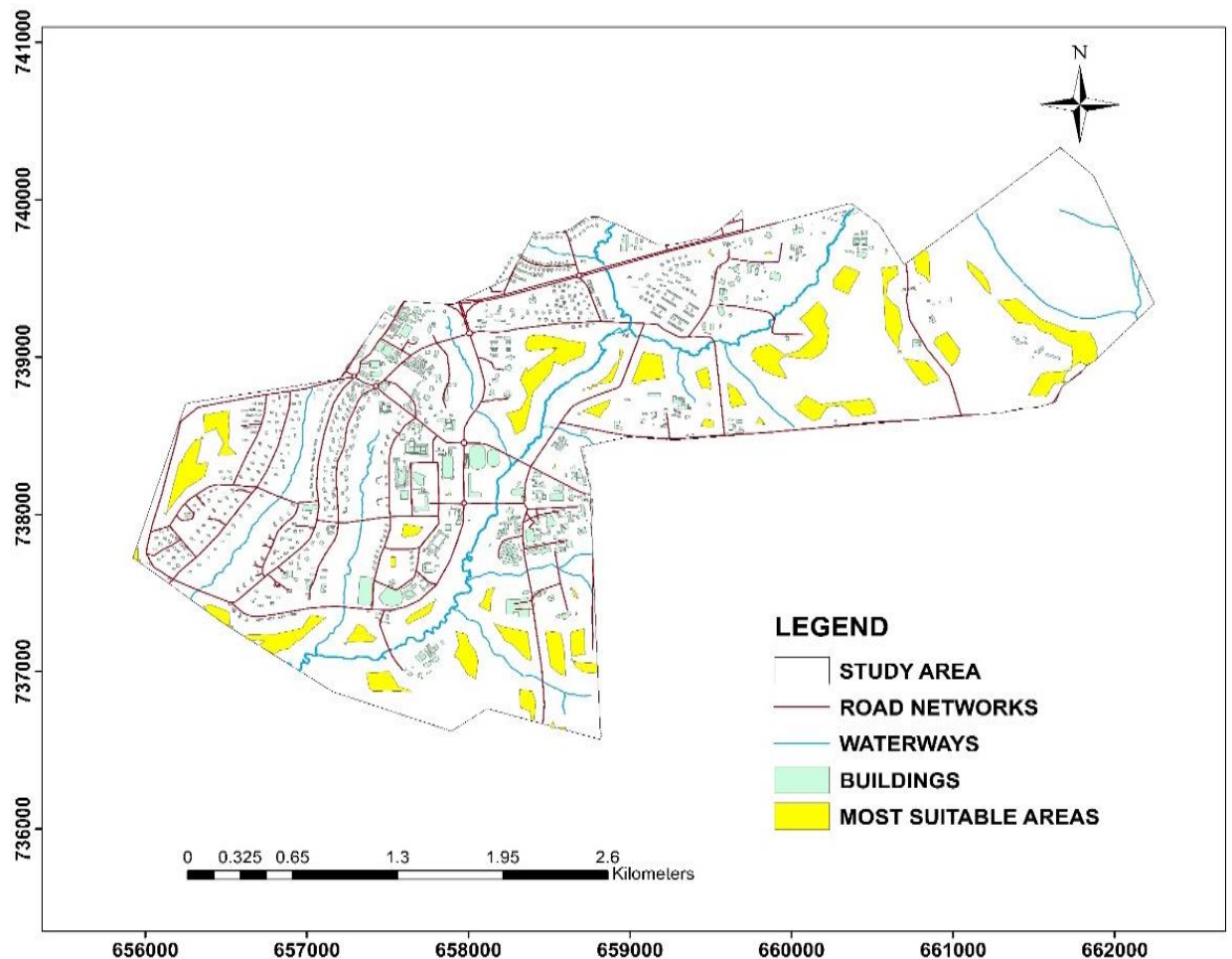

Figure 11. Suitability index map for communal containers

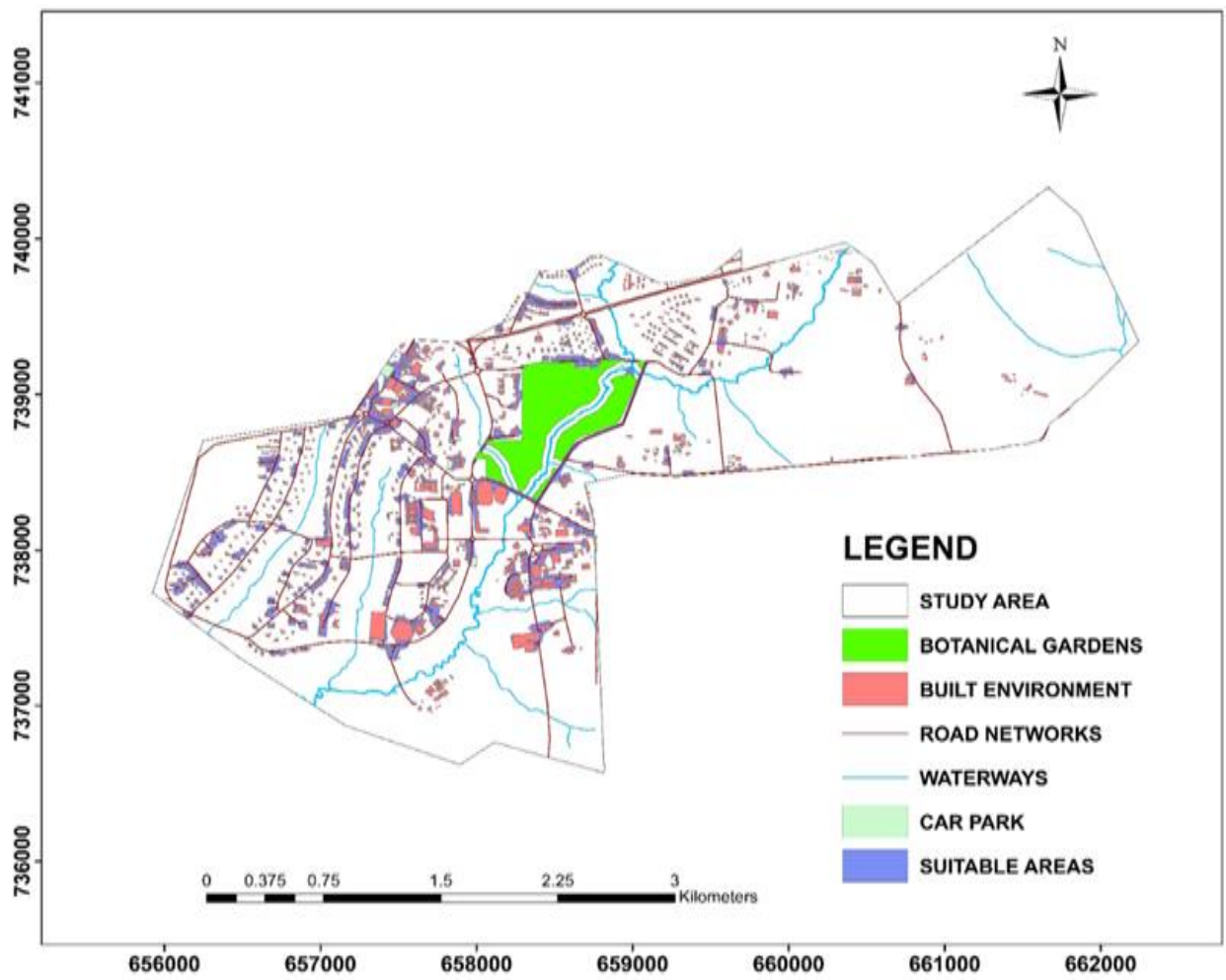

Figure 12. Suitability index map for small containers.

\section{Discussion}

Road network as a criterion plays an important role in transportation and maintaining the aesthetics of an institution. The study area is characterized by well laid roads that ensure easy collection and transport of solid waste to final disposal site. Hamdu (2009) ascribes poor management of waste partly to poorly constructed road networks which lead to breakdown of waste collection trucks and long travel distances with respect to time. Improper siting of solid waste collection containers may cause pollution and also affect traffic flow. Less than 50 $\mathrm{m}$ buffer distance was therefore deemed unsuitable for communal containers whereas due to the nature of the small bins, less than $10 \mathrm{~m}$ was used. The results for roads proximity analysis depicted $32.11 \%$ of most 
suitable area, covering $3.32 \mathrm{~km}^{2}$ for siting communal containers whereas an area of $0.77 \mathrm{~km}^{2}(7.43 \%)$ was considered most suitable for siting small containers in the study area. This is geared towards maintenance of good public health and an environmentally friendly area for students and workers of the university to dwell in.

Limited land space can lead to improper placement of communal containers, raising issues of public health and community agitations. High volume of waste is generated from the faculty, commercial and residential areas since the general student populace on KNUST campus keeps increasing annually. Buffer distances for built area proximity analysis depicting most suitable areas for communal containers was between $100 \mathrm{~m}-$ $250 \mathrm{~m}$ and occupied an area of $2.63 \mathrm{~km}^{2}$ (25.43\%) whiles less than $15 \mathrm{~m}$ represented that for small bins, occupying an area of $0.43 \mathrm{~km}^{2}$ (4.19\%). Placing communal containers beyond $250 \mathrm{~m}$ will be challenging in terms of proximity for generators and collectors of waste. This might call for extra resources for effective operation. Placing the communal containers less than $100 \mathrm{~m}$ to residential buildings wouldn't ensure maintenance of good public health and safety. The nature of small bins however permits placing them comparatively close to residence. Appropriate placement is done to avoid disease outbreak, emission of bad odor, exposure to hazardous chemicals and pests breeding in heaped solid waste.

Water body was considered as a criterion since it is one of the earth's reservoirs whose carrying capacity when exceeded by leachates and other pollutants from disposal sites may cause health hazards (Alemayehu, 2001). The River Wiwi that flows through KNUST campus happens to be a source of drinking water for some people downstream and also serves irrigational purposes. Siting receptacles proximate to a river body can be detrimental to the environment and the health of consumers. Ideally, communal container features; mostly big $\left(12 \mathrm{~m}^{3}\right.$ capacity in the case of study area) and uncovered, storing a lot of waste at a time make it unsuitable to be placed close to a river body. Suitable and most suitable areas for siting communal containers were $3.06 \mathrm{~km}^{2}(29.57 \%)$ and 2.97 $\mathrm{km}^{2}(28.71 \%)$, respectively and from Figure 11 , were within buffer distance ranges of $200 \mathrm{~m}-940 \mathrm{~m}$ and 90 $\mathrm{m}-200 \mathrm{~m}$ respectively. Unlike communal containers, suitable and most suitable areas to site small bins were $0.87 \mathrm{~km}^{2}(8.42 \%)$ and $1.02 \mathrm{~km}^{2}(9.68 \%)$ respectively.

Slope of land is considered in siting communal containers because it affects disposal and collection of solid waste. Very steep areas (slope >15\%) and areas with slope gradient ranging from $0-2 \%$ were deemed unsuitable. This is due to the problem of high run-off during periods of heavy rainfall. The high velocity of running water would transport waste materials from the collection site to other areas which can lead to the pollution of surface waters. The slope suitability results showed that areas most suitable were $7.44 \%$, representing $0.77 \mathrm{~km}^{2}$. Siting waste collection containers in areas having slope gradients between $2-10 \%$ aids in diverting water flow from the areas (Ryan, 2010).
Considering vegetation cover as a criterion for siting small bins, $0.62 \mathrm{~km}^{2}(6.05 \%)$ of KNUST land area was considered most suitable whereas $0.62 \mathrm{~km}^{2}(6.05 \%)$ was considered most suitable. Suitable and most suitable areas for siting small bins considering car park as a criterion were $0.01 \mathrm{~km}^{2}(0.11 \%)$ and $0.01 \mathrm{~km}^{2}(0.91 \%)$ respectively. These two factors where not considered in siting communal containers because they are not compatible due to the nature of communal containers.

Overlaying the thematic maps generated from the environmental factors considered under siting communal containers yielded: $0.73 \mathrm{~km}^{2}(7.08 \%)$ as most suitable area, $1.69 \mathrm{~km}^{2}(16.31 \%)$ as suitable area and $7.93 \mathrm{~km}^{2}$ $(79.58 \%)$ as unsuitable area. For siting small containers, suitable area covered $0.86 \mathrm{~km}^{2}(8.31 \%)$ whiles unsuitable area covered $9.49 \mathrm{~km}^{2}(91.69 \%)$. These findings serve as important tool for identification, comparison and multi-criterion decision making analysis of solid waste containers' proper planning and management as indicated by Parry et al. (2018). Nas et al. (2010) applied same method in the selection of municipal solid waste landfill site for Konya, Turkey and obtained $6.8 \%$ as most suitable area. Environmentally friendly siting of the waste collection containers such as using multi-criteria decision support systems contributes significantly to averting the nuisance and health implications associated with improper siting.

\section{Conclusion}

GIS based multi-criteria selection approach has been used to determine suitable sites to place containers for solid waste collection on KNUST campus. From the suitability map generated for communal containers, it can be concluded that $16.33 \%$ of the landmass of KNUST is suitable and $7.05 \%$ most suitable for environmentally friendly siting of waste collection containers. Suitable area to site small bins within KNUST was $8.31 \%$. Findings from the study serve as a guideline for environmentally friendly receptacle siting and health promotion with efficient land use planning. Decision therefore can be made with good scientific knowledge of the impacts on public health when waste receptacles are placed haphazardly. Other academic institutions can use the findings as a guide to develop and encourage safe and healthy waste collection systems.

\section{References}

Alemayehu, T. (2001). The impact of uncontrolled waste disposal on surface water quality in Addis Ababa, Ethiopia. SINET: Ethiopian Journal of Science, 24(1): 93-104.

Al-Jarrah, O., and Abu-Qdais, H. (2006). Municipal solid waste landfill siting using intelligent system. Waste Management 26(3): 299-306. doi.org/10.1016/j.wasman.2005.01.026

Awunyo-Vitor, D., Ishak, S., and Seidu, J. G. (2013). Urban households' willingness to pay for improved solid waste disposal services in Kumasi Metropolis, Ghana. Urban Studies Research, 2013: 1-8. doi.org/10.1155/2013/659425. 
Ayaim, M. K., Fei-Baffoe, B., Sulemana, A., Miezah, K., and Adams, F. (2019). Potential sites for landfill development in a developing country: A case study of Ga South Municipality, Ghana. Heliyon 5(10), doi.org/10.1016/j.heliyon.2019.e02537.

Bosompem, C., Stemn, E., Fei-Baffoe, B. (2006). Multicriteria GIS-based siting of transfer station for municipal solid waste: The case of Kumasi Metropolitan Area, Ghana. Waste Management and Research, 34(10): 1054-63.

Büyüksalih, İ., Alkan, M., Gazioğlu, C. (2019). Design for 3D city model management using remote sensing and GIS: A case study for the Golden Horn in Istanbul, Turkey, Sigma 37 (4), 1447-1462.

Direk, Ş., Şeker, DZ., Musaoğlu, N., Gazioğlu, C. (2012). Monitoring and Management of Coastal Zones Which are Under Flooding Risk with Remote Sensing and GIS, AGU, Fall Meeting 2012. 1596.

Drobne, S., and Lisec, A. (2009). Multi-attribute decision analysis in GIS: Weighted linear combination and ordered weighted averaging. Informatica, 33(4): 459-474.

Eastman, J. R., Jin, W., Kyem, P. A. K., and Toledano, J. (1995). Raster procedures for multi-criteria/ multiobjective decisions. Photogrammetric Engineering and Remote Sensing, 61(5): 539-54.

Feizizadeh, B., and Blaschke, T. (2013). GISmulticriteria decision analysis for landslide susceptibility mapping: Comparing three methods for the Urmia lake basin, Iran. Natural Hazards, 65(3): 105-2128. doi.org/10.1007/s11069-012-0463-3.

Gorsevski, P. V., Donevska, K. R., Mitrovski, C. D., and Frizado, J. P. (2012). Integrating multi-criteria evaluation techniques with geographic information systems for landfill site selection: A case study using ordered weighted average. Waste Management, 32(2):

287-296. doi.org/10.1016/j.wasman.2011.09.023.

Guerrero, L. A., Maas, G., Hogland, W. (2013). Solid waste management challenges for cities in developing countries. Waste Management, 33(1): 220-232.

Hamdu, I. (2009). Improving waste logistics in Kumasi Metropolitan Area (Master of Science Thesis). Department of Agricultural Engineering, Kwame Nkrumah University of Science and Technology, Kumasi, Ghana.

Jimoh, R., Moradeyo, A., Chuma, V., Olubukola, O., Yusuf, A. (2019). GIS Based Appraisal of Waste Disposal for Environmental Assessment and Management in Mainland Area of Lagos State, NG, International Journal of Environment and Geoinformatics, 6(1), 76-82. doi. 10.30897/ijegeo.476449.

Khorrami, B., Valizadeh Kamran, K., Roostaei, S., (2018). Assessment of Groundwater-Level Susceptibility to Degradation Based on Analytical Network Process (ANP), International Journal of Environment and Geoinformatics, 5(3), 314-324. doi.10.30897/ijegeo.451067.

Miezah, K., Obiri-Danso, K., Kádár, Z., Fei-Baffoe, B., and Mensah, M. Y. (2015). Municipal solid waste characterization and quantification as a measure towards effective waste management in Ghana. Waste Management, 46: 15-27. doi.org/10.1016/j.wasman.2015.09.009.

Mohammad1, M., Hosseınal1, F. (2019). Assessment and Comparison the Location of Six Universities in Tehran City Using GIS and Multi Criteria Decision Making Methods, International Journal of Environment and Geoinformatics, 6(1), 143-147. doi.10.30897/ijegeo.551753.

Nas, B., Cay, T., Iscan, F., Berktay, A. (2010). Selection of MSW landfill site for Konya, Turkey using GIS and multi-criteria evaluation. Environmental Monitoring and Assessment, 160(1-4): 491-500. doi.org/10.1007/s10661-008-0713-8.

Parry, J. A., Ganaie, S. A., Bhat, M. S. (2018). GIS based land suitability analysis using AHP model for urban services planning in Srinagar and Jammu urban centers of JandK, India. Journal of Urban Management, 7(2): 46-56. doi.org/10.1016/ j.jum.2018.05.002.

Ryan, M. (2010). Environmental standards for construction and demolition waste disposal sites.

Saaty, T. L. (1980). The analytic hierarchy process. Volume 1 New York: McGraw-Hill.

Şener, B., Süzen, M. L., and Doyuran, V. (2006). Landfill site selection by using geographic information systems. Environmental Geology, 49(3):376-88.

Şener, Ş., Sener, E., and Karagüzel, R. (2010). Solid waste disposal site selection with GIS and AHP methodology: a case study in Senirkent-Uluborlu (Isparta) Basin, Turkey. Environmental Monitoring and Assessment, 173(1-4): 533-54.

Sulemana, A., Donkor, E. A., Forkuo, E. K., Asantewaa, J., Ankrah, I. N., and Musah, A. M. O. (2020). Optimized routing of trucks for institutional solid waste collection in Kumasi, Ghana. Detritus, 9: 5058, https://doi.org/10.31025/2611-4135/2020.13896.

Vaghela, B., Parmar, M., Solanki, H., Kansara, B., Prajapati, S., Kalubarme, M.(2018). Multi Criteria Decision Making (MCDM) Approach for Mangrove Health Assessment using Geo-informatics Technology. International Journal of Environment and Geoinformatics, 5(2), 114-131, doi.10.30897/ ijegeo.412511.

Walke, N., Reddy, G. O., Maji, A. K., and Thayalan, S. (2012). GIS-based multicriteria overlay analysis in soil-suitability evaluation for cotton (Gossypium spp.): A case study in the black soil region of Central India. Computers and Geosciences, 41:108-18. doi.org/10.1016/j.cageo.2011.08.020. 